\title{
Phenology, yield and fruit quality of ‘Paluma' guava tree at different pruning times
}

\author{
Fenologia, produção e qualidade de frutos da goiabeira 'Paluma' \\ em diferentes épocas de poda
}

\author{
Marlon Jocimar Rodrigues da Silva ${ }^{1 *}$, Marco Antonio Tecchio1, Sofia Domiciano1, \\ Sarita Leonel ${ }^{1}$, Rodrigo Issa Balestrero ${ }^{1}$
}

\author{
'Universidade Estadual Paulista "Júlio de Mesquita Filho“/UNESP, Departamento de Horticultura, Botucatu, SP, Brasil \\ *Corresponding author: marlonjocimar@gmail.com \\ Received in august 16, 2015 and approved in march 21, 2016
}

\begin{abstract}
Pruning guava trees at different times is an important management tool that allows year-long staggering of fruit production. In this context, this study aimed to evaluate the phenological characteristics, yield and fruit quality of the 'Paluma' guava tree at different pruning times in Botucatu, SP. The study used a completely randomized design with four treatments, four replicates and a useful experimental plot plant. The treatments consisted of four different pruning times, August 27, September 11, September 26 and October 11. The following phenological phases were evaluated: branch establishment, flowering, early fruiting, fruit ripening and harvesting. It was determined the number of flower buds, fixed fruits and fixation index fruit were determined. The fruit growth curve was obtained by measuring the transverse and longitudinal diameter. At the time of harvest, the number of fruits per plant, yield and productivity were measured. In the harvested fruits, the fresh mass, the transverse and longitudinal diameter, the flesh and core thickness, the flesh and core mass, soluble solids, titratable acidity and $\mathrm{pH}$ were determined. The 'Paluma' guava trees pruned in August showed higher phenological stage durations than the other pruning times; however, those pruned in early September showed higher fixation index fruit, fruit yield and better physical characteristics. The guava trees pruned in August showed lower titratable acidity values and higher soluble solids/titratable acidity ratio.
\end{abstract}

Index terms: Psidium guajava L.; fruit growth; fruit set; fixation index.

\section{RESUMO}

A poda da goiabeira em diferentes épocas é uma importante prática de manejo que permite a produção escalonada dos frutos ao longo do ano. Nesse contexto, o presente trabalho teve como objetivo avaliar as características fenológicas, produtivas e de qualidade de frutos da goiabeira 'Paluma' em função de diferentes épocas de poda em Botucatu, SP. Foi utilizado o delineamento inteiramente casualizado, com quatro tratamentos, quatro repetições e uma planta útil por parcela experimental. Os tratamentos consistiram em quatro diferentes épocas de poda de goiabeiras 'Paluma', sendo elas: 27 de agosto, 11 de setembro, 26 de setembro e 11 de outubro. Foram avaliadas as seguintes fases fenológicas: estabelecimento de ramos, florescimento, início da frutificação, maturação dos frutos e colheita. Foi determinado o número de botões florais, número de frutos fixados e o índice de pegamento de frutos. A curva de crescimento de frutos foi obtida através da medição semanal do diâmetro transversal e longitudinal dos frutos. Na ocasião da colheita foi avaliado o número de frutos por planta, a produção e a produtividade. Nos frutos colhidos determinou-se a massa fresca; diâmetro transversal, longitudinal e sua relação; espessura do mesocarpo - polpa, e do endocarpo - miolo; massa de polpa e miolo e suas relações; teor de sólidos solúveis, acidez titulável e sua relação e pH. As goiabeiras 'Paluma' podadas no mês de agosto apresentaram maior duração das fases fenológicas que as demais épocas de poda, no entanto juntamente com aquelas podadas no início de setembro apresentaram maiores índice de pegamento de frutos e produção e melhores características físicas dos frutos. As goiabeiras podadas em agosto apresentaram ainda, menores valores de acidez titulável e maiores valores na relação sólidos solúveis/acidez titulável.

Termos para indexação: Psidium guajava L.; crescimento de frutos; frutificação; índice de pegamento.

\section{INTRODUCTION}

The guava has social and economic importance but requires technological advancements to optimize growth (Hojo et al., 2007). Guava producers handle the guava tree to get higher yield, fruit quality and distribute the harvest throughout the year. Among the handling methods, the pruning time stands out as an important management practice. The implementation of scheduled pruning promotes better circulation of cultural practices in the orchard, extends the harvest season, and adds market flexibility (Ramos et al., 2010). According to Hojo et al. (2007), this is an economically viable practice because it can allow the harvest at precise periods of lower market supply. 
Knowledge of the plant phenology, soil conditions and weather conditions in various regions is linked to environmental factors. The importance of certain phenological characterizations during different seasons for guavas to complete the production cycle provides the producer with the basic knowledge of the probable harvest dates and indicates the climatic potential fruit cultivation regions (Hojo et al., 2007).

In addition to assisting in the planning and programming of pruning and harvesting, studying the guava phenological phases is essential for good agricultural practices and crop management. Knowledge of the phenology, specifically the growing conditions, allows more precise cultural programming, phytosanitary treatment and consequently more efficient management practices (Serrano et al., 2008b).

One of the great difficulties in guava orchards is fruit drop. According Manica et al. (2000), despite an initial fruiting rate of up to $54 \%$, some plants only have $6 \%$ of their fruit reach full maturity. In commercial guava orchards, fruit drop may mean reduced income or economic loss to the producer. Faced with the prospect or sharp decline of finding flowers and young fruits, due to pests, diseases or extreme temperatures, there is the possibility to adapt orchard management practices (Corrêa et al., 2002). The fruit fixation index can be used as an early indication of production.
Despite the importance of pruning time, it is essential to determine the effect of this practice on the physical and chemical quality of the fruit. The different climatic conditions that these plants will be submitted over time can directly interfere with the attributes that define guava fruit quality, such as the size of the fruit, the pulp and core features, soluble solids, $\mathrm{pH}$ and titratable acidity. These characteristics define the fate of the produced fruit because the 'Paluma' guava can be destined for fresh consumption or for industry (Gonzaga Neto et al., 1991; Manica et al., 1998).

The objective of this study was to evaluate the phenological characteristics, yield and fruit quality of 'Paluma' guava trees in Botucatu, SP after pruning at different times.

\section{MATERIAL AND METHODS}

The experiment was conducted in the experimental orchard of the Horticulture Department at Faculdade de Ciências Agronômicas - UNESP, Botucatu, SP, situated at $22^{\circ} 55^{\prime} 55^{\prime \prime} \mathrm{S}, 48^{\circ} 26^{\prime} 22^{\prime \prime} \mathrm{W}$, with an altitude of 810 meters above sea level, from August 2013 to April 2014.

The predominant climate type is warm temperate (mesothermal), with rainy summers and dry winters (Cwa - Köeppen), an average annual temperature of $20.5^{\circ} \mathrm{C}$ and an average annual rainfall of $1,533 \mathrm{~mm}$. Climatic data for the research period is shown in Figure 1. The soil of the area was classified as UDULT according to previously

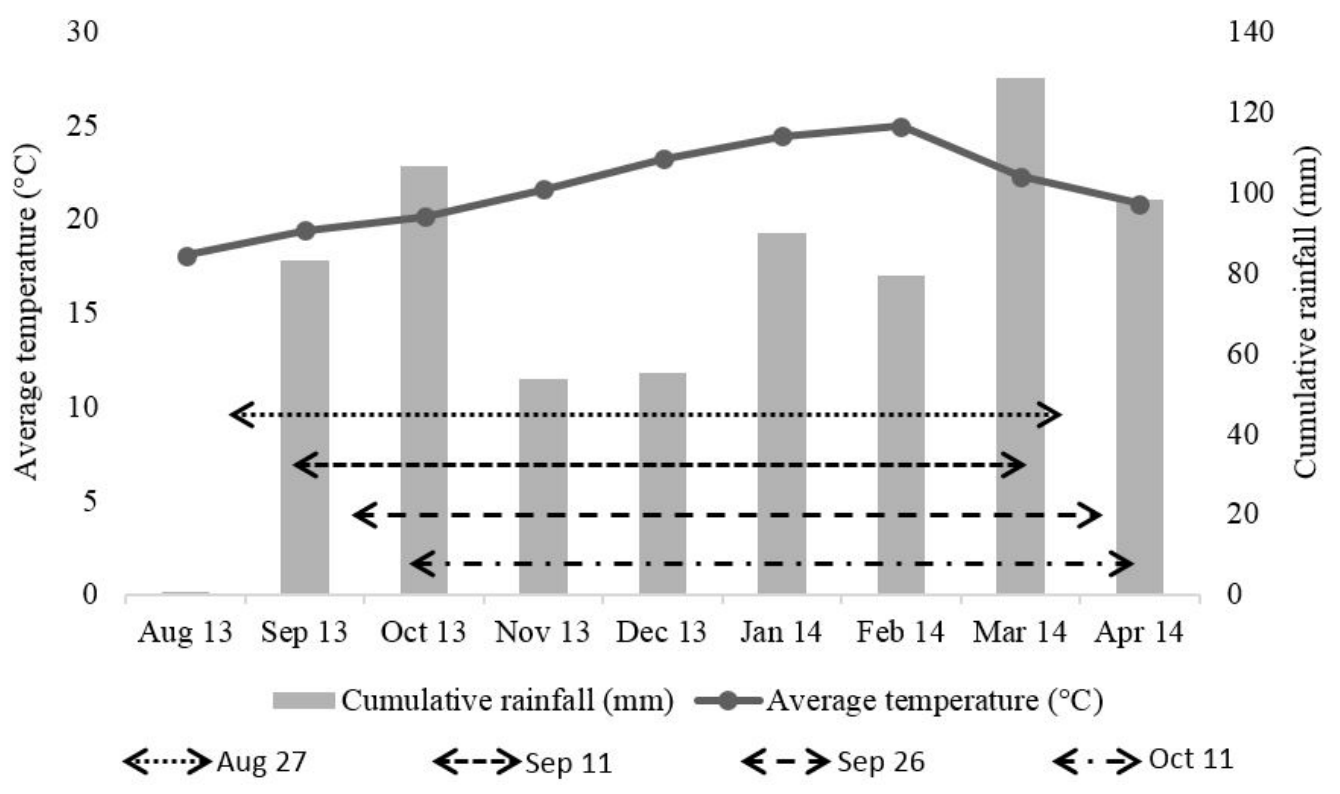

Figure 1: Climatic data of Botucatu, SP from August 2013 to April 2014. Left arrow indicates the date of pruning and right arrow indicates harvest fruit each season pruning. 
published criteria (Empresa Brasileira de Pesquisa Agropecuária - Embrapa, 2006). The experimental unit soil has the chemical properties following: $\mathrm{pH}\left(\mathrm{CaCl}_{2}\right)$ 5.14 , organic matter $=21.8 \mathrm{~g} \mathrm{dm}^{-3}, \mathrm{Ca}^{+2}=34.5 \mathrm{mmolc}$ $\mathrm{dm}^{-3}, \mathrm{Mg}^{+2}=11.4$ mmolc dm ${ }^{-3}, \mathrm{~K}^{+}=1.34$ mmolc dm $\mathrm{dm}^{-3}$, $\mathrm{H}^{+}+\mathrm{Al}^{+3}=36.9 \mathrm{mmolc} \mathrm{dm}^{-3}$, sum of bases $=47.3 \mathrm{mmolc}$ $\mathrm{dm}^{-3}, \mathrm{~T}=84.2 \mathrm{mmolc} \mathrm{dm}^{-3}$ and base saturation $=56.3 \%$.

The treatments consisted of different pruning times (P) of the 'Paluma' guava tree, as follows: P1 - August 27, P2 - September 11, P3 - September 26, and P4 - October 11. The guava trees were 9 years old and planted in orchards without irrigation with $6 \mathrm{~m}$ between rows and $4.5 \mathrm{~m}$ between plants. Pruning shortened the branches to $1 / 3$ of the original length (average pruning), without consideration for the branch diameter. The recommended culture treatments were used in the period between pruning and harvesting.

From the day of pruning to harvest the fruits, 10 branches per plant, in accordance with methodology of Serrano et al. (2008b), were assessed for the following phenological phases: 1 - branch establishment, at least two pairs of fully developed leaves; 2 - flowering (anthesis); 3 - early fruiting, beginning with the fall of the stylus; 4 - fruit maturation, early shift from green color of the fruit peel; and 5 - harvesting. Phenophases are expressed as the days after pruning (DAP).

At the beginning of anthesis, the number of flower buds (NFB) in 10 productive established branches, the early stage of maturation, and the number of fixed fruits (NFF) were determined. With this data, the fixation index fruits (FIF) - fruit set was determined, using the formula proposed by Corrêa et al. (2002): FIF $=[(\mathrm{NFF} / \mathrm{NFB}) 100]$. A total of 10 fruits per experimental plot were selected and measured weekly using a digital caliper. The transverse and longitudinal diameter of the fruits yielded a growth curve.

Fruit harvest occurred at physiological maturity, i.e., when the skin color was at maturity stage 3 (Yellow Green) (Azzolini; Jacomino; Spoto, 2004). At the time of harvest, the number of fruits per plant and fresh fruit weight were evaluated to calculate the yield $\left(\mathrm{kg}\right.$ plant $\left.^{-1}\right)$ and productivity $\left(\mathrm{t} \mathrm{ha}^{-1}\right)$, based on a 370 stand plants $\mathrm{ha}^{-1}$. The harvested fruit was taken to a horticulture laboratory at FCA/UNESP, and the laboratory conducted physicochemical assessments. 40 fruit per treatment were evaluated for the following: fresh fruit mass (g), as weighed individually on a precision scale; transverse fruit diameter (TFD) and longitudinal fruit diameter (LFD), using a digital caliper and both expressed in $\mathrm{mm}$; and the TFD/LFD ratio. After being opened along the longitudinal axis, each fruit was evaluated for the following: mesocarp (flesh) thickness (FT), endocarp (core) thickness (CT), both expressed in mm; the FT/CT ratio; flesh mass (FM) and core mass $(\mathrm{CM})$, both expressed in $\mathrm{g}$; and the FM/ CM ratio.

After crushing the fruit to obtain a homogenized extract of flesh and core, we measured the following chemical parameters: $\mathrm{pH}$, through direct reading in the extract obtained using pot Digimed DMPH-second mark; soluble solids (SS), as expressed in ${ }^{\circ}$ Brix and determined by direct refractometry; titratable acidity (TA), obtained by titrating $5 \mathrm{~g}$ of the flesh and core homogenized extract, which was diluted into $100 \mathrm{~mL}$ of distilled water with a standardized solution of sodium hydroxide at $0.1 \mathrm{~N}$ and phenolphthalein as an indicator, and is expressed in grams of citric acid per $100 \mathrm{~g}$ of total extract; and SS/TA ratio (Brasil, 2005).

For phenological and physical-chemical fruit characteristic assessment, a completely randomized design with four treatments and four replicates was used. For the growth curve, a completely randomized design with split plots, four replicates and 10 fruit per repetition was designed. The plots represented different pruning times, and subplots were different evaluation times (days after onset of fruiting).

The data were analyzed by ANOVA with Tukey's test correction, with 5\% significance in the plots and regression analysis subplots, and the models were chosen based on the coefficient of determination significance $\left(\mathrm{R}^{2} \geq 0.70\right)$. For the other variables, the data were subjected to ANOVA compared by Tukey's test at 5\% significance. All analysis used the statistical program SISVAR (Ferreira, 2011).

\section{RESULTS AND DISCUSSION}

Pruning times of the 'Paluma' guava tree significantly influenced the duration of plants phenological phases (Table 1).

In plants pruned on August 27, there were a higher number of days after pruning (DAP) in the branch establishment phase, flowering (anthesis) and early fruiting characteristics being 46,72 and $84 \mathrm{DAP}$, respectively. The guava trees pruned on October 11 required fewer days to reach the same phenological stages. This effect was due to different climatic conditions at the pruning time because the plants pruned on August 27 were subjected to lower temperatures (average temperature $18^{\circ} \mathrm{C}$ ) and less rainfall $\left(0.5 \mathrm{~mm}\right.$ ) compared to October (average temperature $20.1^{\circ} \mathrm{C}$ e rainfall $106.7 \mathrm{~mm}$ ). Guava trees pruned on September 11 and 26 showed intermediate values that did not differ significantly from each other. 
Table 1: Phenophases, number of fruits per branch and fixation index fruit of the 'Paluma' guava tree at different pruning times.

\begin{tabular}{|c|c|c|c|c|c|c|c|}
\hline \multirow{2}{*}{ Pruning times } & BET & FLR & EFR & IFM & HVT & FPB & $\mathrm{FIF}$ \\
\hline & \multicolumn{6}{|c|}{--------------- days after pruning --------------- } & 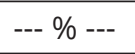 \\
\hline 27/08/13 & $46.75 \mathrm{a}$ & $72.18 \mathrm{a}$ & $84.27 \mathrm{a}$ & $204.5 \mathrm{a}$ & $211.1 \mathrm{a}$ & $1.60 a b$ & $32.77 \mathrm{ab}$ \\
\hline $11 / 09 / 13$ & $31.09 \mathrm{~b}$ & $55.43 \mathrm{~b}$ & $65.54 \mathrm{~b}$ & $183.1 \mathrm{~b}$ & $185.8 \mathrm{~b}$ & $2.25 \mathrm{a}$ & 40.38 a \\
\hline $26 / 09 / 13$ & $28.91 \mathrm{~b}$ & $54.51 \mathrm{~b}$ & $64.27 \mathrm{~b}$ & $185.9 \mathrm{~b}$ & $192.7 \mathrm{~b}$ & $1.38 \mathrm{~b}$ & $24.02 \mathrm{~b}$ \\
\hline $11 / 10 / 13$ & $25.75 c$ & $48.78 \mathrm{c}$ & $57.28 \mathrm{c}$ & $179.5 b$ & $185.8 \mathrm{~b}$ & $0.73 \mathrm{~b}$ & $20.45 b$ \\
\hline CV (\%) & 3.75 & 3.57 & 3.75 & 2.46 & 3.17 & 28.01 & 22.77 \\
\hline MSD & 2.61 & 4.32 & 5.34 & 9.71 & 12.90 & 0.87 & 14.06 \\
\hline
\end{tabular}

*BET: branch establishment; FLR: flowering; EFR: early fruiting; IFM: early fruit maturation; HVT: harvesting; FPB: fruits per branch; FIF: fixation index fruit. Means followed by the same letters in column do not differ by Tukey test $(p<0.05)$. CV: coefficient of variation; MSD: minimum significant difference.

According to Hojo et al. (2007), the guava tree is very responsive to pruning, and new shoots arise after branch cutting. In general, a faster emergence of new shoots and branch establishment means a shorter time for bloom occurrence.

The longest time interval among the assessed phenological phases occurred between the early fruiting and early fruit maturation stages, which was expected because this is the fruit growth period for both length and diameter. This interval was similar in the four evaluated pruning times, with an average of 120 days.

Plants pruned on August 27 required 204 DAP to reach the beginning of fruit maturation, which differed from the other pruning times that required an average of 182 DAP to achieve the same phase. The time interval between fruit pruning and harvesting was higher in guava trees pruned on August 27, which required 211 DAP, 23 days more than the guava trees pruned on September 11, September 26 and October 11, in which the harvesting stage was reached at 185, 192 and 195 DAP, respectively.

Hojo et al. (2007) reported that the shortest pruning cycle is probably related to the average temperature of the period, the available soil water and rainfall. Thus, it can be said that these climatic factors were more effective during early fruiting because the number of days between this phenological stage and the harvest was similar in all of the pruning times studied with $126.8,120.3,128.4$ and 128.5 days for the pruning held on August 27, September 11, September 26 and October 11 , respectively.

The highest fruit per branch and fixation index fruits were obtained from guava trees pruned on September
$11,2.25$ and $40.38 \%$, respectively, though this was not significantly different from guava trees pruned on August 27 , which showed 1.6 fruits per branch and $32.77 \%$ fruit set. The lowest values were observed in plants pruned on September 26 and October 11, among which there was no significant difference.

Corrêa et al. (2002) evaluated the fixation index fruits in 'Pedro Sato', 'Paluma' and 'Rica' guava trees in Taquaritinga, SP and found average values of $32.3 \%$, $18.7 \%$ and $12.2 \%$, respectively. The values found by these authors were lower than those obtained in this study. This difference may be related to different climatic conditions, orchard management or even plant spacing. The fixation index fruits is an important characteristic because it can be used as an early indicator of production, even in commercial guava orchards, as fruit drop may mean reduced income or economic loss to the producer (Corrêa et al., 2002; Serrano et al., 2008a).

There was a significant interaction in fruit growth, both the transverse and longitudinal diameters, and the different pruning times, days of assessment (days after anthesis - DAA), the initial fruit growth and final fruit growth phase (Table 2). In the intervening period, between 42 and 91 DAA, there was little increase in the size of the fruit, and there was no significant interaction.

The guava fruit had a double sigmoidal growth curve and both the transverse and longitudinal diameter (Figure 2) were characterized by three phases. Phase I was a period that begins shortly after anthesis that was characterized by an exponential growth due mainly to fruit cell division. Phase II was a relatively slow growth period during which the seeds mature. And Phase III was an exponential growth period, 
when there was a change in skin color and the fruit ripened (Salazar et al., 2006; Serrano et al., 2008b). The driving of phases I, II and III were similar among the four times of pruning studied being 49,42 and 35 days, respectively.

The number of fruit per plant of guava trees pruned on August 27 and September 11 was higher than that found in guava trees pruned on September 26 and October 11, with no differences between either of the two groups (Table 3 ).

Ramos et al. (2010) evaluated 'Paluma' guava trees under subtropical climate conditions in São Manuel, SP and found that plants pruned in August produced greater numbers of fruit compared to those pruned in September and October. However, Serrano et al. (2007) evaluated pruning times in 'Paluma' guava trees in Pedro Canário, ES from November to February, and they found that February is the best time to get more fruit.
The mean fruit yield and productivity were higher in trees pruned on August 27 and September 11, likely because these trees had greater numbers of fruit. The highest fresh fruit mass was obtained in plants pruned on September 11, though it did not differ significantly from those pruned on August 27 and September 26. The increase in average fruit weight is directly related to the number of fruits per plant (Gonzaga Neto; Leodido; Silva, 1997); however, it was not observed in this study. Ramos et al. (2010) found heavier fruit in guava trees pruned in August that did not differ from those pruned in September and October. The authors state the results provide guava producers practical responses because pruning may be indicated for the production of table guavas, where the fruit size is a requirement for consumer market interest.

Table 2: Transverse and longitudinal diameter guava fruit from 7 to 126 days after anthesis (DAA).

\begin{tabular}{|c|c|c|c|c|c|c|c|c|}
\hline \multirow{3}{*}{ DAA } & \multicolumn{4}{|c|}{ Longitudinal fruit diameter (mm) } & \multicolumn{4}{|c|}{ Transverse fruit diameter $(\mathrm{mm})$} \\
\hline & \multicolumn{8}{|c|}{ 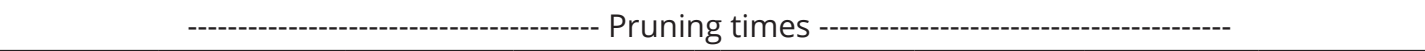 } \\
\hline & Aug 27 & Sep 11 & Sep 26 & Oct 11 & Aug 27 & Sep 11 & Sep 26 & Oct 11 \\
\hline 7 & $16.34 \mathrm{~A}$ & $18.83 \mathrm{~A}$ & $13.21 \mathrm{~A}$ & $19.43 \mathrm{~A}$ & $11.20 \mathrm{~A}$ & $13.48 \mathrm{~A}$ & $9.10 \mathrm{~A}$ & $14.03 \mathrm{~A}$ \\
\hline 14 & $21.38 \mathrm{~A}$ & $25.18 \mathrm{~A}$ & $18.91 \mathrm{~A}$ & $23.66 \mathrm{~A}$ & $13.76 \mathrm{AB}$ & $17.32 \mathrm{AB}$ & $12.10 \mathrm{~B}$ & $18.74 \mathrm{~A}$ \\
\hline 21 & $24.18 \mathrm{AB}$ & $28.37 \mathrm{~A}$ & 20.78 B & $28.86 \mathrm{~A}$ & 17.72 BC & $20.92 \mathrm{AB}$ & $14.36 \mathrm{C}$ & $23.49 \mathrm{~A}$ \\
\hline 28 & $27.18 \mathrm{AB}$ & $30.26 \mathrm{AB}$ & $23.23 \mathrm{~B}$ & $32.42 \mathrm{~A}$ & $21.38 \mathrm{BC}$ & $23.83 \mathrm{AB}$ & $16.57 \mathrm{C}$ & $27.81 \mathrm{~A}$ \\
\hline 35 & $28.93 \mathrm{~A}$ & $31.77 \mathrm{~A}$ & $27.57 \mathrm{~A}$ & $34.18 \mathrm{~A}$ & 23.65 B & $25.81 \mathrm{AB}$ & 22.34 B & $30.26 \mathrm{~A}$ \\
\hline 42 & $33.80 \mathrm{~A}$ & $35.90 \mathrm{~A}$ & $32.38 \mathrm{~A}$ & $35.19 \mathrm{~A}$ & $28.85 \mathrm{~A}$ & $29.93 \mathrm{~A}$ & $26.23 \mathrm{~A}$ & $30.56 \mathrm{~A}$ \\
\hline 49 & $36.71 \mathrm{~A}$ & $37.94 \mathrm{~A}$ & $35.69 \mathrm{~A}$ & $35.32 \mathrm{~A}$ & $31.33 \mathrm{~A}$ & $31.84 \mathrm{~A}$ & $30.15 \mathrm{~A}$ & $30.61 \mathrm{~A}$ \\
\hline 56 & $37.71 \mathrm{~A}$ & $38.61 \mathrm{~A}$ & $36.84 \mathrm{~A}$ & $35.51 \mathrm{~A}$ & $32.31 \mathrm{~A}$ & $32.83 \mathrm{~A}$ & $31.01 \mathrm{~A}$ & $30.71 \mathrm{~A}$ \\
\hline 63 & $37.91 \mathrm{~A}$ & $38.89 \mathrm{~A}$ & $37.47 \mathrm{~A}$ & $36.85 \mathrm{~A}$ & $32.46 \mathrm{~A}$ & $33.08 \mathrm{~A}$ & $31.45 \mathrm{~A}$ & $31.90 \mathrm{~A}$ \\
\hline 70 & $38.09 \mathrm{~A}$ & $39.64 \mathrm{~A}$ & $37.69 \mathrm{~A}$ & $37.89 \mathrm{~A}$ & $32.60 \mathrm{~A}$ & $33.26 \mathrm{~A}$ & $31.72 \mathrm{~A}$ & $32.79 \mathrm{~A}$ \\
\hline 77 & $38.21 \mathrm{~A}$ & $40.00 \mathrm{~A}$ & $37.93 \mathrm{~A}$ & $38.80 \mathrm{~A}$ & $32.94 \mathrm{~A}$ & $33.41 \mathrm{~A}$ & $32.14 \mathrm{~A}$ & $34.13 \mathrm{~A}$ \\
\hline 84 & $38.27 \mathrm{~A}$ & $41.24 \mathrm{~A}$ & $38.74 \mathrm{~A}$ & $40.23 \mathrm{~A}$ & $33.60 \mathrm{~A}$ & $33.47 \mathrm{~A}$ & $32.98 \mathrm{~A}$ & $35.51 \mathrm{~A}$ \\
\hline 91 & $40.15 \mathrm{~A}$ & $42.39 \mathrm{~A}$ & $40.22 \mathrm{~A}$ & $42.70 \mathrm{~A}$ & $34.46 \mathrm{~A}$ & $36.09 \mathrm{~A}$ & $34.37 \mathrm{~A}$ & $35.52 \mathrm{~A}$ \\
\hline 98 & $41.53 \mathrm{~A}$ & $46.36 \mathrm{~A}$ & $42.75 \mathrm{~A}$ & $48.54 \mathrm{~A}$ & $36.48 \mathrm{AB}$ & $41.23 \mathrm{AB}$ & 35.86 B & $41.82 \mathrm{~A}$ \\
\hline 105 & $45.91 \mathrm{~A}$ & $50.62 \mathrm{~A}$ & $45.25 \mathrm{~A}$ & $52.24 \mathrm{~A}$ & $40.21 \mathrm{BC}$ & $46.02 \mathrm{~A}$ & $38.46 \mathrm{C}$ & $45.64 \mathrm{AB}$ \\
\hline 112 & 49.28 B & $53.47 \mathrm{AB}$ & $47.49 \mathrm{~B}$ & $57.21 \mathrm{~A}$ & $45.14 \mathrm{AB}$ & $49.34 \mathrm{~A}$ & 41.42 B & $49.77 \mathrm{~A}$ \\
\hline 119 & 55.67 B & $57.34 \mathrm{AB}$ & $54.40 \mathrm{~B}$ & $63.98 \mathrm{~A}$ & $50.21 \mathrm{AB}$ & $52.75 \mathrm{~A}$ & 46.39 B & $54.43 \mathrm{~A}$ \\
\hline 126 & $58.72 \mathrm{AB}$ & $63.14 \mathrm{AB}$ & 55.98 B & $65.78 \mathrm{~A}$ & $53.75 \mathrm{AB}$ & $58.72 \mathrm{~A}$ & 50.34 B & $57.75 \mathrm{~A}$ \\
\hline CV (\%) & \multicolumn{4}{|c|}{5.88} & \multicolumn{4}{|c|}{6.08} \\
\hline
\end{tabular}

Means followed by the same letters in line do not differ by Tukey test $(p<0.05)$. 

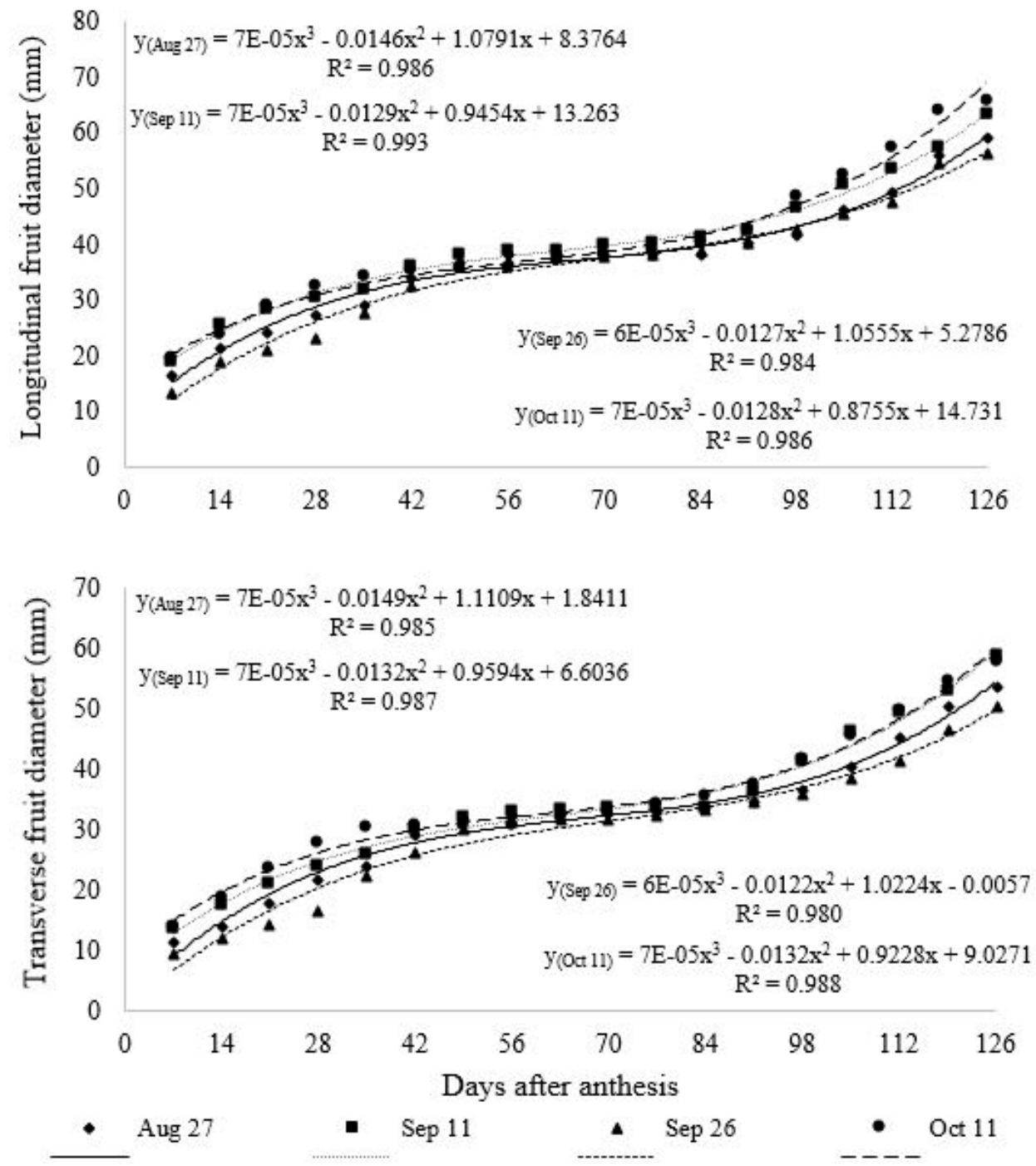

Figure 2: Transverse and longitudinal diameter of the 'Paluma' guava tree fruit at different pruning times.

Table 3: Production and physical characteristics of 'Paluma' guava tree fruit at different pruning times. BotucatuSP, 2013/2014.

\begin{tabular}{cccccccc}
\hline Pruning times & FPP & yield $\left(\mathrm{kg} \mathrm{plant}^{-1}\right)$ & PDT $\left(\mathrm{t} \mathrm{ha}{ }^{-1}\right)$ & FFM $(\mathrm{g})$ & TFD $(\mathrm{mm})$ & LFD $(\mathrm{mm})$ & TFD/LFD \\
\hline $27 / 08 / 13$ & $1519.5 \mathrm{a}$ & $175.4 \mathrm{a}$ & $64.98 \mathrm{a}$ & $122.9 \mathrm{ab}$ & $68.1 \mathrm{a}$ & $73.1 \mathrm{a}$ & $0.93 \mathrm{a}$ \\
$11 / 09 / 13$ & $1390.5 \mathrm{a}$ & $170.9 \mathrm{a}$ & $63.30 \mathrm{a}$ & $125.3 \mathrm{a}$ & $62.9 \mathrm{~b}$ & $67.1 \mathrm{~b}$ & $0.94 \mathrm{a}$ \\
$26 / 09 / 13$ & $967.5 \mathrm{~b}$ & $104.4 \mathrm{~b}$ & $38.68 \mathrm{~b}$ & $107.2 \mathrm{~b}$ & $58.5 \mathrm{c}$ & $61.9 \mathrm{c}$ & $0.95 \mathrm{a}$ \\
$11 / 10 / 13$ & $679.0 \mathrm{~b}$ & $75.29 \mathrm{~b}$ & $27.89 \mathrm{~b}$ & $116.6 \mathrm{ab}$ & $60.1 \mathrm{bc}$ & $67.2 \mathrm{~b}$ & $0.90 \mathrm{~b}$ \\
\hline CV (\%) & 15.94 & 20.73 & 20.73 & 22.99 & 8.32 & 10.51 & 5.94 \\
MSD & 381.3 & 57.26 & 21.21 & 15.76 & 3.02 & 4.11 & 0.032 \\
\hline
\end{tabular}

Means followed by the same letters in column do not differ by Tukey test ( $<0.05)$. FPP: Fruit per plant; PDT: productivity; FFM: fresh fruit mass; TFD: transversal fruit diameter; LFD: Iongitudinal fruit diameter; TFD/LFD ratio. CV: coefficient of variation; MSD: minimum significant difference. 
This study found that the fruit from plants pruned on August 27 showed greater transverse and longitudinal diameters. As for the relationship between these variables, significant differences between the first three pruning times were not observed, but significance was present in fruit from the pruning on October 11. This relationship between the fruit's longitudinal and transverse diameter (LFD/TFD ratio) indicates the fruit shape. The pear-shaped or oval fruit (LFD/ TFD greater than 1) is more suited to natural consumption, while those with rounded shapes (LFD/TFD next to 1) are best suited for use as industrial raw material (Gonzaga Neto et al., 1991). Ramos et al. (2010) did not find significant differences in the values of the TFD/LFD ratio when plants were pruned in August, October and November.

There was a significant difference in the flesh thickness (FT) and core thickness (CT) between the different pruning times (Table 4).

Flesh thickness values were in the range of 9.83 $\mathrm{mm}$ (August 27) and $8.45 \mathrm{~mm}$ (September 26). Core thickness was the lowest in fruit from plants pruned on August $27(38.49 \mathrm{~mm})$ and largest in those pruned on October $11(42.02 \mathrm{~mm})$. The FT/CT ratio was highest in the first two pruning times, and these values were not significantly different from each other. We obtained higher flesh mass values in fruit from plants pruned on August 27 and November 11, but these values did not significantly differ from those pruned on October 11.

There was no significant difference between the four pruning times in terms of core mass, and the average was $37.36 \mathrm{~g}$. The highest $\mathrm{FM} / \mathrm{CM}$ ratio were observed in fruit from plants pruned on August 27 and September 11 , with average values of 2.35 and 2.29 , respectively. The 'Paluma' guava fruit can be utilized in both in natura consumption and industrially; in this case, mainly candy and pulp production. Thus, a higher pulp/core ratio can be advantageous for industrial yield (Amorim et al., 2015). The authors studying the same cultivar in Vista Alegre do Alto, SP obtained similar values to those found in this study.

We obtained a higher $\mathrm{pH}$ value in fruit from guava trees pruned on August 27 (Table 5). pH values greater than 3.50 indicate the need to add edible organic acids in the processing of the fruit to achieve a higher quality final product for industrial use. However, high $\mathrm{pH}$ values suggest the possibility of deterioration in industrial

Table 4: Physical characteristics of 'Paluma' guava fruit at different pruning times.

\begin{tabular}{cccclll}
\hline Pruning times & FT $(\mathrm{mm})$ & $\mathrm{CT}(\mathrm{mm})$ & FT/CT & FM $(\mathrm{g})$ & $\mathrm{CM}(\mathrm{g})$ & $\mathrm{FM} / \mathrm{CM}$ \\
\hline $27 / 08 / 13$ & $9.83 \mathrm{a}$ & $38.49 \mathrm{c}$ & $0.26 \mathrm{a}$ & $85.74 \mathrm{a}$ & $36.58 \mathrm{a}$ & $2.35 \mathrm{a}$ \\
$11 / 09 / 13$ & $9.45 \mathrm{ab}$ & $40.17 \mathrm{bc}$ & $0.24 \mathrm{a}$ & $86.65 \mathrm{a}$ & $38.14 \mathrm{a}$ & $2.29 \mathrm{ab}$ \\
$26 / 09 / 13$ & $8.45 \mathrm{c}$ & $41.20 \mathrm{ab}$ & $0.21 \mathrm{~b}$ & $69.35 \mathrm{~b}$ & $36.79 \mathrm{a}$ & $1.90 \mathrm{c}$ \\
$11 / 10 / 13$ & $8.65 \mathrm{bc}$ & $42.02 \mathrm{a}$ & $0.21 \mathrm{~b}$ & $77.97 \mathrm{ab}$ & $37.95 \mathrm{a}$ & $2.06 \mathrm{bc}$ \\
CV (\%) & 17.77 & 7.76 & 18.31 & 26.71 & 19.72 & 20.70 \\
MSD & 0.94 & 1.82 & 0.024 & 12.40 & 4.28 & 0.26 \\
\hline
\end{tabular}

Means followed by the same letters in column do not differ by Tukey test $(p<0.05)$. FT: Flesh thickness; CT: core thickness; FT/ CT ratio; FM: flesh mass; CM: core mass; FM/CM ratio. CV: coefficient of variation; MSD: minimum significant difference.

Table 5: Average chemical characteristics of the 'Paluma' guava tree fruit at different pruning times.

\begin{tabular}{ccccc}
\hline Pruning times & $\mathrm{pH}$ & $\mathrm{SS}\left({ }^{\circ}\right.$ Brix $)$ & TA $\left(\mathrm{g} 100^{-1}\right.$ acid citric $)$ & SS/TA \\
\hline $27 / 08 / 13$ & $3.90 \mathrm{a}$ & $10.81 \mathrm{a}$ & $0.31 \mathrm{~d}$ & $35.92 \mathrm{a}$ \\
$11 / 09 / 13$ & $3.82 \mathrm{~b}$ & $10.64 \mathrm{a}$ & $0.54 \mathrm{a}$ & $19.57 \mathrm{c}$ \\
$26 / 09 / 13$ & $3.79 \mathrm{~b}$ & $11.10 \mathrm{a}$ & $0.45 \mathrm{~b}$ & $24.54 \mathrm{~b}$ \\
$11 / 10 / 13$ & $3.78 \mathrm{~b}$ & $10.66 \mathrm{a}$ & $0.41 \mathrm{c}$ & $26.08 \mathrm{~b}$ \\
\hline CV (\%) & 0.71 & 5.65 & 5.60 & 12.12 \\
MSD & 0.037 & 0.833 & 0.033 & 4.428 \\
\hline
\end{tabular}

Means followed by the same letters in column do not differ by Tukey test $(p<0.05)$. SS: soluble solids; TA: titratable acidity; SS/ TA ratio. CV: coefficient of variation; MSD: minimum significant difference. 
products, and the appropriate threshold of 4.20 is needed for the best product preservation (Manica et al., 1998). The values found in this study are slightly below the $\mathrm{pH}$ range that is considered adequate.

There was no significant difference in the soluble solid content of the fruit. The values obtained were higher than those from the same cultivar that were found by Souza et al. (2010) in São Manuel, SP, Cavalini et al. (2015) in Vista Alegre do Alto, SP, or by Brackmann et al. (2012) in Santa Maria, RS (10.1, 8.6 and $7.7^{\circ}$ Brix, respectively). The titratable acidity after pruning on September 11

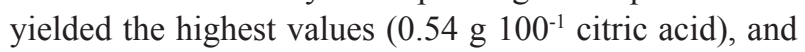
those pruned in August 27 had the lowest titratable acidity $\left(0.31 \mathrm{~g} 100^{-1}\right.$ citric acid). The acidity is directly related to quality of fruit, and for fresh consumption, fruit with low acidity levels is preferred (Cavalini et al., 2015). These authors found acidity similar to those obtained in this study.

The SS/TA ratio demonstrated the strongest relationship in August (35.92) and the weakest in early September (19.57) due to lower and higher results titratable acidity, respectively. The soluble solids rates found in this study are similar to those found by Ramos et al. (2010), who pruned 'Paluma' guava trees grown in São Manuel, $\mathrm{SP}$ at different times. However, the current study found no significant difference in assessing the $\mathrm{pH}$, TA and SS/ TA ratio of the fruit. Serrano et al. (2007) worked with 'Paluma' guava trees under a different cropping system and analyzed associations between the pruning time and intensity of fructification. They observed that the magnitude of winter pruning did not affect the SS or TA content or the relationship between them. However, the fruit is influenced by the type of cultivation system used and by the time of the systematic pruning.

\section{CONCLUSIONS}

The 'Paluma' guava trees pruned in August showed higher phenological stage duration than the other pruning times; however, both August and early September pruning showed a higher fruit fixation index, yield and better physical characteristics. The guava trees pruned in August showed lower titratable acidity values and a higher soluble solids/titratable acidity ratio.

\section{REFERENCES}

AMORIM, D. A. de et al. Adubação nitrogenada e potássica em goiabeiras 'Paluma': I. Efeito na produtividade e na qualidade dos frutos para industrialização. Revista Brasileira de Fruticultura, 37(1):201-209, 2015.
AZZOLINI, M.; JACOMINO, A. P.; SPOTO, M. H. F. Estádios de maturação e qualidade pós-colheita de goiabas. Revista Brasileira de Fruticultura, 26(1):29-31, 2004.

BRACKMANN, A. et al. Atmosfera controlada para o armazenamento de goiaba cultivar 'Paluma'. Revista Ceres, 59(2):151-156, 2012.

BRASIL. Métodos físico-químicos para análise de alimentos. $1^{\circ}$ ed. Brasília: Ministério da Saúde. Agência Nacional de Vigilância Sanitária, 2005. 1018p.

CAVALINI, F. C. et al. Ponto de colheita e qualidade de goiabas 'Kumagai' e ‘Paluma'. Revista Brasileira de Fruticultura, 37(1):64-72, 2015.

CORRÊA, M. C. M. et al. Índice de pegamento de frutos em goiabeiras. Revista Brasileira de Fruticultura, 24(3):783786, 2002.

EMBRAPA. Centro Nacional de Pesquisa de Solos. Sistema Brasileiro de Classificação de Solos. $2^{\circ}$ ed Rio de Janeiro: Embrapa Solos; 2006. 306p.

FERREIRA, D. F. Sisvar: a computer statistical analysis system. Ciência e Agrotecnologia. 35(6):1039-1042, 2011.

GONZAGA NETO, L.; LEODIDO, J. M. C.; SILVA, E. E. G. Raleamento de frutos de goiabeira cv. Rica em Juazeiro, BA, Brasil. Pesquisa Agropecuaria Brasileira, 32(12):1281-1286, 1997.

GONZAGA NETO, L. et al. Comportamento produtivo de goiabeiras no Vale do Rio Moxotó-Ibimirim-PE. III. Seleções para o consumo natural do fruto, onze anos de produção. Revista Brasileira de Fruticultura, 13(1):17-24, 1991.

HOJO, R. H. et al. Caracterização fenológica da goiabeira ‘Pedro Sato' sob diferentes épocas de poda. Revista Brasileira de Fruticultura, 29(1):20-24, 2007.

MANICA, I. et al. Goiaba. Fruticultura Tropical, 6. Porto Alegre: Cinco Continentes; 2000. 374p.

MANICA, I. et al. Competição entre quatro cultivares e duas seleções de goiabeira. Pesquisa Agropecuaria Brasileira, 33(8):1305-1313, 1998.

RAMOS, D. P. et al. Produção e qualidade de frutos da goiabeira 'Paluma', submetida à diferentes épocas de poda em clima subtropical. Revista Ceres, 57(5):659-664, 2010.

SALAZAR, D. M. et al. Phenological stages of the guava tree (Psidium guajava L.). Scientia Horticulturae, 108:157-161, 2006.

SERRANO, L. A. L. et al. Fenologia da goiabeira 'Paluma' sob diferentes sistemas de cultivos, épocas e intensidades de poda de frutificação. Bragantia, 67(3):701-712, 2008a. 
Goiabeira 'Paluma' sob diferentes sistemas de cultivo, épocas e intensidades de poda de fruticifação. Pesquisa Agropecuaria Brasileira, 42(6):785-792, 2007.

Características fenológicas e produtivas da goiabeira "paluma" podada em diferentes épocas e intensidades no norte fluminense. Revista Ceres, 55(5):416-424, 2008b.

SOUZA, M. E. Influência das precipitações pluviométricas em atributos físico-químicos de frutos 'Paluma' em diferentes estádios de maturação. Revista Brasileira de Fruticultura, 32(2):637-646, 2010. 